\title{
Influence of Host Resistance on the Genetic Structure of the White Pine Blister Rust Fungus in the Western United States
}

\author{
B. A. Richardson, N. B. Klopfenstein, P. J. Zambino, G. I. McDonald, B. W. Geils, and L. M. Carris
}

First, second, third, and fourth authors: U.S. Department of Agriculture (USDA) Forest Service, Rocky Mountain Research Station, Moscow, Idaho 83843; first and sixth authors: Washington State University, Department of Plant Pathology, Pullman 99164; and fifth author: USDA Forest Service, Rocky Mountain Research Station, Flagstaff, AZ 86001.

Accepted for publication 7 December 2007.

\begin{abstract}
Richardson, B. A., Klopfenstein, N. B., Zambino, P. J., McDonald, G. I., Geils, B. W., and Carris, L. M. 2008. Influence of host resistance on the genetic structure of the white pine blister rust fungus in the western United States. Phytopathology 98:413-420.

Cronartium ribicola, the causal agent of white pine blister rust, has been devastating to five-needled white pines in North America since its introduction nearly a century ago. However, dynamic and complex interactions occur among $C$. ribicola, five-needled white pines, and the environment. To examine potential evolutionary influences on genetic structure and diversity of $C$. ribicola in western United States, population genetic analyses of $C$. ribicola were conducted using amplified fragment length polymorphism (AFLP) molecular markers. The fungus was sampled at six sites. Collections for two of the six sites were from separate plantings of resistant-selected western white pine and sugar pine.
\end{abstract}

ABSTRACT
Heterozygosity based on polymorphic loci among populations ranged from 0.28 to 0.40 , with resistant-selected plantations at the extremes. Genetic differentiation was also highest between these two populations. Principal coordinates analysis and Bayesian assignment placed most isolates that are putative carriers of virulence to major-gene resistance into a discernable cluster, while other isolates showed no clustering by site or host species. These results indicate that $C$. ribicola in western North America is not genetically uniform, despite its presumed single site of introduction and relatively brief residence. Moreover, major-gene resistance appears to have imposed strong selection on the rust, resulting in reduced genetic diversity. In contrast, no evidence of selection was observed in C. ribicola from hosts that exhibit only multigenic resistance.

Additional keywords: qualitative and quantitative resistance.
Invasive species are a primary threat to ecosystem function and biodiversity (53), yet they provide excellent opportunities to study ecological and coevolutionary processes over short time scales $(1,56)$. Rapidly evolving organisms have been often described as species colonizing new environments (49) where several genetic processes are at work (33). Given the capacity of invasive species to evolve rapidly and well-documented accounts of introductions and spread, studies addressing evolutionary genetics on ecological timescales (e.g., decades) are feasible. Such studies are critical for understanding invasive processes and for developing effective management of invasive species.

Disease epidemics caused by novel plant-pathogen associations can be attributed to a basic compatibility and limited coevolution and/or to genetic changes that enables pathogens to exploit new hosts (8). Invasive forest pathogens, such as Cryphonectria parasitica (Murr.) Barr (causal agent of chestnut blight), have virtually eliminated North American hosts because of limited or nonexistent native host resistance and/or lack of effective antagonists (2). However, other invasive pathogens, such as Cronartium ribicola Fisch. in Rabenth., the white pine blister rust (WPBR) fungus, display variable infection rates across the landscape that can be partially attributed to host resistance (42). Such novel hostpathogen interactions in natural ecosystems provide valuable insights into coevolutionary processes of invasive pathogens.

Host resistance plus pathogen virulence and aggressiveness are controlling influences on coevolution of plant pathosystems.

Corresponding author: B. A. Richardson; E-mail address: brichardson02@fs.fed.us

doi:10.1094/PHYTO-98-4-0413

This article is in the public domain and not copyrightable. It may be freely reprinted with customary crediting of the source. The American Phytopathological Society, 2008.
Studies of an endemic flax-rust pathosystem have shown local coadaptation, with spatial and temporal dynamics in plant resistance and pathogen virulence $(59,60)$. This pathosystem displays a gene-for-gene relationship for resistance and virulence (11), and diversity in host resistance is positively associated with diversity in pathogen virulence (58). Similar findings have been reported for other biotrophic pathosystems with gene-for-gene resistance (32). Less is known about pathosystems where the host varies in multigenic resistance (i.e., quantitative resistance) and the pathogen varies in aggressiveness. Studies with the necrotrophic fungus Alternaria brassicicola have found that growth rates are highly variable in vitro, with a positive correlation between growth rates and seasonal disease increase (57). Impacts of different resistance mechanisms (i.e., major-gene resistance versus multigenic resistance) and planting of resistant-selected versus unselected plants on the genetic structure of pathogens in otherwise natural ecosystems remain largely unexplored.

C. ribicola has caused widespread disruption of five-needled white pine ecosystems in North America (39). This obligate, macrocyclic rust, alternates between white pines and alternate hosts in two families: most Ribes species of the Grossulariaceae and some species of Pedicularis and Castilleja in the Orobanchaceae. Parasitism of Orobanchaceae species was only recently discovered in North America (40); however, the ability to infect these hosts is widespread in North America (51). This rust fungus has a putative origin in eastern Asia from where it was introduced to Europe and subsequently to North America (20). Separate introductions have occurred in eastern and western North America via western Europe $(44,55)$. The pathogen was presumably introduced in 1910 to western North America on a single shipment of eastern white pine (Pinus strobus L.) seedlings from a French nursery to Point Grey, British Columbia, Canada. However, 
multiple introductions from nurseries in France and Germany were reported for eastern North America (39). Despite intensive control programs in the early 20th century (35), the pathogen has spread to diverse ecosystems, infecting eight species of fiveneedled white pine in North America.

Genetic studies at different spatial scales have provided insight into the mating system and population genetic structure of C. ribicola in North America. Each canker typically represents one haploid individual, but fertilization of its receptive hyphae by spermatia from multiple cankers can produce a mosaic of genotypes among its dikaryotic aeciospores $(13,15,63)$. Analysis of DNA marker profiles of haploid spermatia and basidiospores has shown that fertilization in natural $C$. ribicola populations is predominately through sexual outcrossing $(12,14)$. High gene flow among populations and/or recent introduction was proposed to explain low partitioning of genetic diversity among eastern Canada populations (9). However, comparisons of C. ribicola samples from across North America indicated considerable differentiation between eastern and western populations. This differentiation suggests an effective gene-flow barrier (i.e., the Great Plains) between these two regions (16). However, Kinloch et al. (31) found that even adjacent $C$. ribicola populations in western North America had substantial genetic structure. For example, a population obtained from Ribes among major-generesistant sugar pine (P. lambertiana Doug.) at Happy Camp, California was the most divergent of populations sampled from eastern and western United States, including sites in North Carolina and Virginia.

Resistance to $C$. ribicola in five-needled white pines can be categorized as two types: major-gene resistance (i.e., gene-forgene) and multigenic resistance (i.e., quantitative resistance).

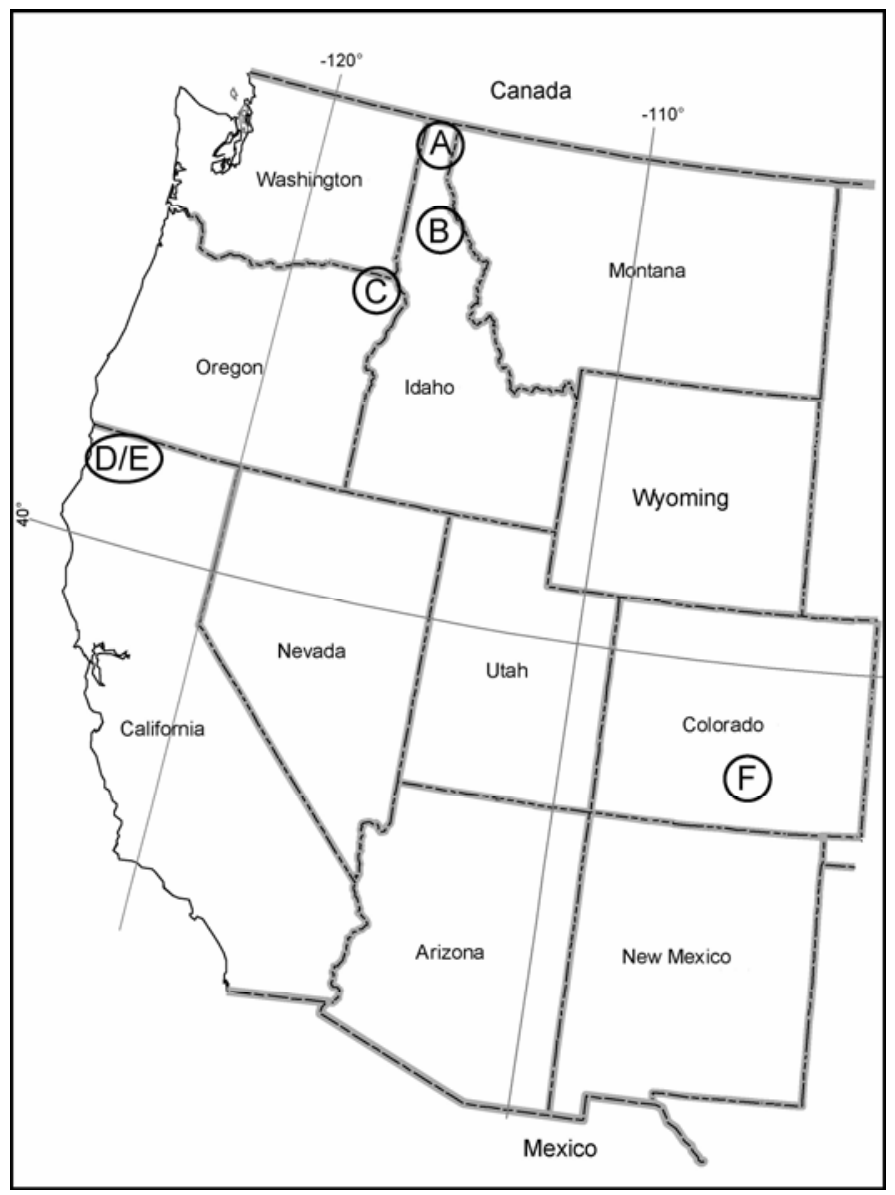

Fig. 1. Sites sampled for Cronartium ribicola in the western United States. $A=$ Roman Nose, B = Merry Creek, C = Standley Springs, D = Happy Camp, E = Klamath Mountains, and $\mathrm{F}=$ Mosca Pass.
Major-gene resistance conferring a hypersensitive response to avirulent races of $C$. ribicola is present at low frequencies in natural populations of at least three white pine species (27). Putative genotypes $\mathrm{Cr} 1$ and $\mathrm{Cr} 2$ for major-gene resistance, present in sugar pine and western white pine ( $P$. monticola Dougl. ex D. Don), are overcome by $C$. ribicola carrying specific putative virulence genotypes vcrl and $v c r 2$, respectively $(26,28)$. In addition, Kinloch et al. $(29,30)$ found that vcrl and $v c r 2$ typically co-occurred with $\mathrm{Cr} 1$ and $\mathrm{Cr} 2$, whereas verl and vcr2 were usually absent in white pine populations that lacked the resistance genes. Presently, major-gene resistance is unknown in western white pine populations of Idaho, Montana or eastern Washington.

Multigenic resistance phenotypes appear to be more widespread and have been the focus of white pine breeding programs for more than 50 years (41). Unlike major-gene resistance that affects presence or absence of $C$. ribicola infection by an "all-ornothing" hypersensitive reaction, multigenic resistance contributes to a variety of phenotypic reactions. Multigenic resistance can prevent or slow infection and colonization, impede sporulation, and shorten the persistence of the rust in its pine hosts (41). Hypothetically, these two types of resistance could impact genetic structure and evolution of the rust.

As with its hosts, western North American populations of C. ribicola inhabit discontinuous and diverse environments. Environments range between extremes represented by mesic coastal sites with western white pine or sugar pine and more xeric subalpine sites with whitebark pine ( $P$. albicaulis Engl.), limber pine ( $P$. flexilis James), southwestern white pine ( $P$. strobiformis Engelm.), bristlecone pine (P. aristata Engel.), or foxtail pine (Pinus balfouriana Grev. and Balf.). In addition, biotic factors, such as disease resistance (30) and population genetic structure (50), differ among host species. This abiotic and biotic environmental heterogeneity may contribute to a high variation in disease incidence over the landscape (42). In the current study, we used amplified fragment length polymorphism (AFLP) markers to: (i) examine genetic diversity and differentiation within and among western North American populations of C. ribicola, (ii) investigate the effects of differing types of host resistance and host species on $C$. ribicola isolates and populations, and (iii) identify AFLP loci that behave as if linked to loci undergoing environmental selection.

\section{MATERIALS AND METHODS}

Site characteristics. $C$. ribicola was sampled from six sites: three in the inland northwestern United States (Roman Nose, ID; Merry Creek, ID; and Standley Springs, OR), two in the Klamath Mountains of northern California (Klamath Mountains and Happy Camp), and one in the Rocky Mountains of southern Colorado (Mosca Pass) (Fig. 1). These sites represent different environments and hosts (Table 1). Roman Nose, Mosca Pass, and Standley

TABLE 1. Site host and genetic information for Cronartium ribicola samples

\begin{tabular}{lclcc}
\hline Population & $n$ & Aecial host $^{\mathrm{a}}$ & $\% \mathrm{P}^{\mathrm{b}}$ & $\mathrm{H}^{\mathrm{c}}$ \\
\hline Roman Nose (RN) & 29 & WWP/WBP & 97.6 & 0.367 \\
Merry Creek (MC) & 22 & WWP-F2 & 100 & 0.407 \\
Standley Springs (SS) & 25 & WBP & 97.6 & 0.401 \\
Happy Camp (HC) & 25 & SP-MGR & 95 & 0.285 \\
Klamath Mountains (KM) & 22 & SP, WWP, FTP & 92.5 & 0.327 \\
Mosca Pass (MP) & 25 & LP, BCP & 95 & 0.337 \\
\hline
\end{tabular}

a Five-needled pine hosts at each site include western white pine (WWP), whitebark pine (WBP), sugar pine (SP), foxtail pine (FTP), limber pine (LP), and bristlecone pine (BCP).

b \% P, percentage of polymorphic loci of total polymorphic loci.

${ }^{\mathrm{c}} \mathrm{H}$, mean heterozygosity of polymorphic loci.

${ }^{d}$ Second-generation resistant families of WWP (6) planted in 1970.

e Trees prescreened for major gene resistance against wild-type $C$. ribicola and outplanted in 1991, 1993, 1994, 1995, or 1997. 
Springs are natural stands. Two are plantations of resistantselected white pines: (i) Happy Camp, with sugar pine prescreened for major-gene resistance (26), and (ii) Merry Creek, with western white pine bred for multigenic resistance (37). The last, Klamath Mountains, is a composite collection of $C$. ribicola infecting sugar pine, western white pine, and foxtail pine in close proximity to the Happy Camp site. All isolates from the Klamath Mountains were collected from host trees either known to lack major-gene resistance or of unknown status for this form of resistance, which is particularly rare in natural stands in the vicinity of the Happy Camp site (24).

Fungal isolates. Bulk aeciospores were collected from single cankers by scraping spores into a microfuge tube. The sampling strategy varied slightly with age and composition of the sites. In general, sampling was completed with transects across $1 \mathrm{~km}^{2}$ area with approximate intervals of $>10 \mathrm{~m}$ between collections. For resistance plantations, sampling was completed within a smaller area with shorter sampling intervals to obtain the necessary samples. Aeciospores were used to inoculate leaf disks (approximately $20 \mathrm{~mm}$ diameter) of the 'Heimburger' clone of Ribes nigrum L., a universal suscept $(46,64)$ grown in a greenhouse. Leaf disks were washed with tap water and placed on moist filter paper in a $150 \times 15 \mathrm{~mm}$ petri plate. Spores were inoculated onto the abaxial surface of the leaf disk with a sterile pipette tip and misted with distilled water. The petri plates were sealed and then incubated at $18^{\circ} \mathrm{C}$ for 2 weeks under a 12 -h day length. The seal was punctured after $24 \mathrm{~h}$ to reduce humidity. One leaf disk per plate was used as a negative control.

To insure that a sample consisted of a single genotype, leaf disk-derived urediniospores from single uredinia were collected using a dissecting microscope and a minuten pin $(0.1 \mathrm{~mm}$ diameter) and inoculated onto leaves of potted $R$. nigrum plants. Leaves were misted with water, covered with plastic bags and incubated at $18^{\circ} \mathrm{C}$ for $24 \mathrm{~h}$. Plants were then moved to the greenhouse and placed into individual inoculation chambers. To obtain approximately 50 to $100 \mathrm{mg}$ of urediniospores for each isolate, 5 to $10 \mathrm{mg}$ of uredinospores were collected from the first inoculation, then used to inoculate a new plant. The second inoculation was achieved by suspending urediniospores in $600 \mu \mathrm{l}$ of distilled water and misting four to five leaves with the spore solution using aerosol sprayers. After 2 weeks, the urediniospores were collected into gelatin capsules and dried to $40 \%$ relative humidity $(\mathrm{RH})$ before DNA extraction and storage. DNA extraction followed a modified protocol developed by Zambino (65) using $10 \mathrm{mg}$ of urediniospores.

AFLP analysis. A modified AFLP procedure was adapted from Vos et al. (62). Approximately $300 \mathrm{ng}$ of genomic DNA was digested for $3 \mathrm{~h}$ at $37^{\circ} \mathrm{C}$ followed by $65^{\circ} \mathrm{C}$ for $20 \mathrm{~min}$ in a reaction containing 10 units of EcoRI and 5 units $M s e I$ (New England Biolabs, Inc., Ipswich, MA) in a total volume of $20 \mu \mathrm{l}$. DNA fragments were ligated at $16^{\circ} \mathrm{C}$ for $8 \mathrm{~h}$ using $60 \mathrm{U}$ of T4 ligase (New England Biolabs, Inc.) with $50 \mu \mathrm{M} \mathrm{MseI}$ and $5 \mu \mathrm{M}$ $E c o$ RI adapters in final reaction volume of $20 \mu \mathrm{l}$. Ligated fragments were then diluted 1:10 with sterile-distilled water. Each pre-amplification polymerase chain reaction (PCR) $(30-\mu$ total volume) contained $6 \mu \mathrm{l}$ of template, $300 \mathrm{nM} \mathrm{EcoRI} \mathrm{and} \mathrm{MseI}$ primers with no extensions, $10 \times \mathrm{PCR}$ buffer, $3 \mathrm{mM} \mathrm{MgCl}_{2}$, $200 \mu \mathrm{M}$ dNTPs, and 1.5 units of AmpliTaq polymerase (Applied Biosystems, Inc., Foster City, CA). Selective amplification was conducted using eight combinations of MseI and EcoRI primers with +2 extensions. The nucleotide extension combinations were as follows: GT-GA, GA-AG, CC-GA, CA-AC, GT-AC, GT-TA, CC-TT, and GT-AT for EcoRI and MseI, respectively. Reactions (25- $\mu$ l total volume) contained $5 \mu \mathrm{l}$ of $1: 10$ diluted pre-amplification product, $1 \times$ PCR buffer, $2.4 \mathrm{mM} \mathrm{MgCl}_{2}, 300 \mu \mathrm{M}$ dNTPs, $100 \mathrm{nM}$ MseI primer, and 1.5 units of AmpliTaq Gold polymerase (Applied Biosystems, Inc.). The EcoRI primer was labeled with fluorescent dye 6-FAM (Integrated DNA Technologies, Coral- ville, IA). All reactions were conducted using an MJ PTC-200 thermocycler (Bio-Rad Laboratories, Waltham, MA). The thermocycling protocol has been previously described (48). To ensure consistency in the AFLP procedure, several samples were processed at least twice from DNA extraction to band scoring. In addition, negative controls were created for each reaction step.

After a 1:4 dilution with sterile distilled water, selective amplification products were separated on an ABI 3700 DNA automated sequencer (Applied Biosystems, Inc.) at the University of Wisconsin Biotechnology Center (Madison, WI) using Geneflo-625 (50 to $625 \mathrm{bp}$, CHIMERx, Inc., Milwaukee, WI) as an internal standard. Genotyper 3.7 NT (Applied Biosystems, Inc.) was used to score bands in a size range of 75 to $600 \mathrm{bp}$ using a scaled peakheight threshold of 100 or greater. AFLP bands were then visually checked for all samples and scored for presence (1) or absence (0).

Data analyses. Polymorphic AFLP marker bands were only analyzed if shared by two or more individuals. Since samples were derived from dikaryotic cells and AFLPs are dominant markers, genetic diversity and distance values were calculated with AFLP-SURV version 1.0 (61) using a Bayesian method to estimate the frequency of null alleles (66) following the Lynch and Milligan (34) method and assuming Hardy-Weinberg equilibrium. Unbiased expected heterozygosity within and among populations (45) was calculated using the Lynch and Milligan (34) method. An unpaired $t$ test was used to test for significant differences in heterozygosity among populations.

To estimate upper and lower $95 \%$ confidence intervals for $\mathrm{F}_{\mathrm{ST}}$ values and develop bootstrap support for genetic distances between sites, individuals were randomly resampled using AFLPSURV for 1,000 iterations. A pairwise genetic-distance matrix between populations was graphically displayed by neighbor joining using NEIGHBOR and bootstrapping with CONSENSE from PHYLIP version 3.6 (10). Principal coordinates analysis was used to determine relationships among individual samples. NTSYS-PC version 2.10 (52) was used to create a Jaccard similarity matrix of isolates that was transformed with the d-center module and plotted for the three principal coordinates that explained the largest variances.

Genetic structure was also analyzed using STRUCTURE version 2.0, a model-based method for determining the number of populations (K) with probabilistic assignment of individuals (47). Dominant AFLP data were treated as genotypic (i.e., two alleles per locus) by coding recessive alleles as missing data. This data set was run under both an admixture and nonadmixture model with similar results (nonadmixture model shown). To estimate the appropriate number of populations, six different population parameters were run ( $K=1$ to 6 ) with a 'burn-in' period of 20,000 iterations and 200,000 repetitions.

Because Beaumont and Nichols (4) determined that relationships between $\mathrm{F}_{\mathrm{ST}}$ and heterozygosity are robust under a variety of demographic and mutation models, this model provided a sta-

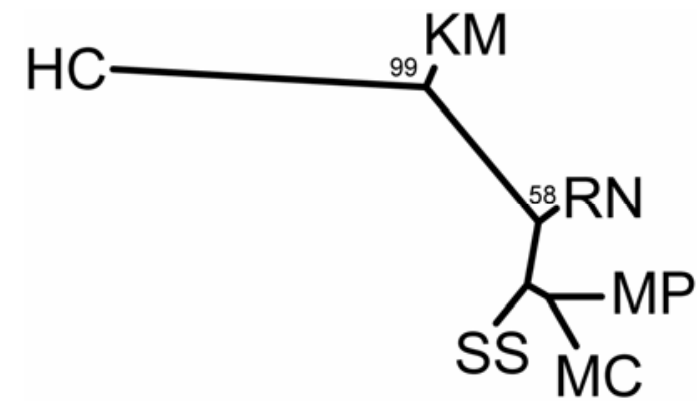

Fig. 2. Neighbor-joining dendrogram based on Nei's genetic distance estimates between Cronartium ribicola populations. Bootstrap estimates $>50 \%$ are provided at the nodes. $\mathrm{MC}=$ Merry Creek, MP $=$ Mosca Pass, SS $=$ Standley Springs, RN = Roman Nose, $\mathrm{HC}=$ Happy Camp, and $\mathrm{KM}=$ Klamath Mountains. 
tistical basis to screen genetic loci for a signature of selection. A modified version of this statistical model, DF $_{\text {DIST }}$ (3), which uses a Bayesian method for estimating the null (recessive) allele frequencies for dominant markers, has been developed for dominant loci (66). This simulation model was run 50,000 times using the six sites as populations. Based on the $\mathrm{F}_{\mathrm{ST}}$ distribution, 0.95 bounds were created. These bounds were then corrected for multiple tests using a false discovery rate (5).

\section{RESULTS}

Eight combinations of selective primers produced 437 AFLP bands among 148 C. ribicola isolates. Only 42 of 437 (9.6\%) loci were polymorphic. As discussed later, one polymorphic locus was removed from the analyses because it deviated from neutral expectations leaving a total of 41 loci. Despite the low levels of polymorphic loci, all $C$. ribicola isolates had unique AFLP profiles, except two samples collected from adjacent whitebark pines at Roman Nose. Expected heterozygosity for the polymorphic loci was 0.386 among all sites, while average within-site heterozygosity was 0.354 . The remaining variation (0.032) represented variation among sites. However, heterozygosity varied by site, with the highest within-site heterozygosity of variable loci occurring at Merry Creek (0.406) and the lowest occurring at Happy Camp (0.285) (Table 1). Happy Camp had significantly lower heterozygosity than Merry Creek, Standley Springs, and Roman Nose $(P<0.01)$.

Significant genetic structure was found among sites $\left(\mathrm{F}_{\mathrm{ST}}=\right.$ $0.082, P<0.001)$. From pairwise comparisons of collection sites, Nei's estimate of genetic distance was highest between Happy Camp and other sites. This is illustrated in a neighbor-joining dendrogram (Fig. 2). Values ranged from 0.109 between Happy Camp and Merry Creek to 0.037 between Klamath Mountains and Mosca Pass. Lower genetic distance estimates were found among the inland northwestern and Mosca Pass sites and between sites at Happy Camp and Klamath.

Relationships among individual isolates reflected differentiation among sites. Principal coordinates 1 and 2 explained a small portion of the total variation, $14.8 \%(9.1+5.7 \%$, respectively). However, ordination with two principal coordinates placed most of the Happy Camp isolates along with approximately half of Klamath isolates into a discernable group. Aside from the Happy Camp cluster, isolates showed no discernable pattern of clustering by site or host species in plots of two to three principal coordinates (plot of two principal coordinates, Fig. 3; three principal coordinates not shown).

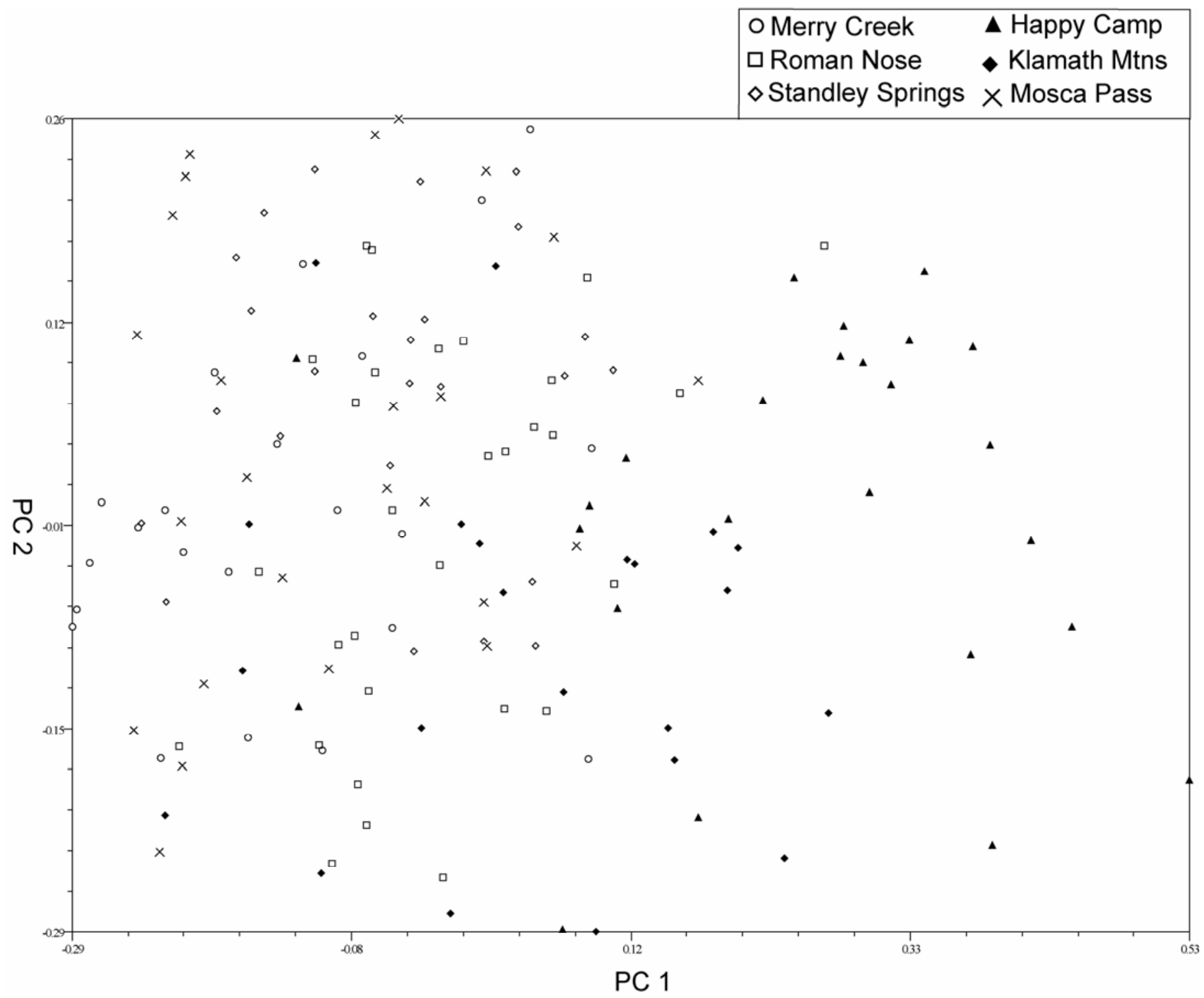

Fig. 3. Principal coordinates (PC) plot of Cronartium ribicola isolates. The plot was generated from a Dice's similarity matrix using NTsYS software (51). PC 1 and 2 with eigenvalues of 4.37 and 2.72 out of a total 47.9 explain 9.1 and $5.7 \%$ of the variation, respectively. 
Analysis of AFLP loci using model-based assignment supported the principal coordinate analysis. The probability that the data fit a discrete number of populations was at a maximum $(99.8 \%)$ when tested for three populations and declined with increasing populations. A bar plot (Fig. 4) illustrates the assignment probabilities based on three populations. Nearly all isolates from the inland sites (Merry Creek, Roman Nose, Standley Springs, and Mosca Pass) show high probability of assignment to populations 1 or 2 , with no pattern of assignment associated with site. In contrast, of the reflecting patterns seen in the principal coordinates analysis, all but two Happy Camp isolates (exceptions HC20 and HC24) show high probability of assignment to population 3. The Klamath Mountain isolates show a similar pattern to Happy Camp; however, a greater proportion of isolates ( 8 out of 21$)$ have higher probability $(P<0.70)$ of assignment to populations 1 and 2 (Fig. 4).

Comparisons of AFLP loci among sites detected three loci (7.1\% of polymorphic loci) that fell above the upper bounds of $\mathrm{F}_{\mathrm{ST}}(P<0.05)$. The loci are plotted according to heterozygosity and estimated $\mathrm{F}_{\mathrm{ST}}$ (Fig. 5). These three loci (GT-AT134, GTAC57B, and GT-AT129) had highly significant deviation $\left(\mathrm{F}_{\mathrm{ST}}>\right.$ 0.27 ) and two had large frequency differences between Happy Camp and other sites (Fig. 6). However, only one locus, GT-

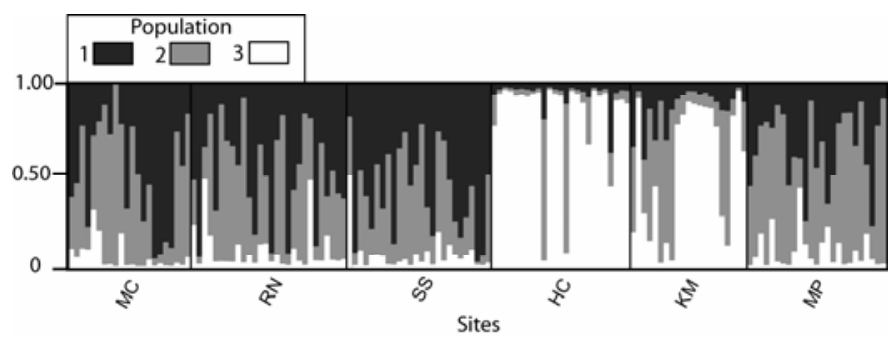

Fig. 4. A Bayesian model-based approach using the program STRUCTURE to assign isolates to program-generated populations (46). Pictured are isolate assignments to three populations. Individual isolates are represented by bars. $\mathrm{MC}=$ Merry Creek, MP = Mosca Pass, $\mathrm{SS}=$ Standley Springs, RN = Roman Nose, $\mathrm{HC}=$ Happy Camp, and KM = Klamath Mountains.

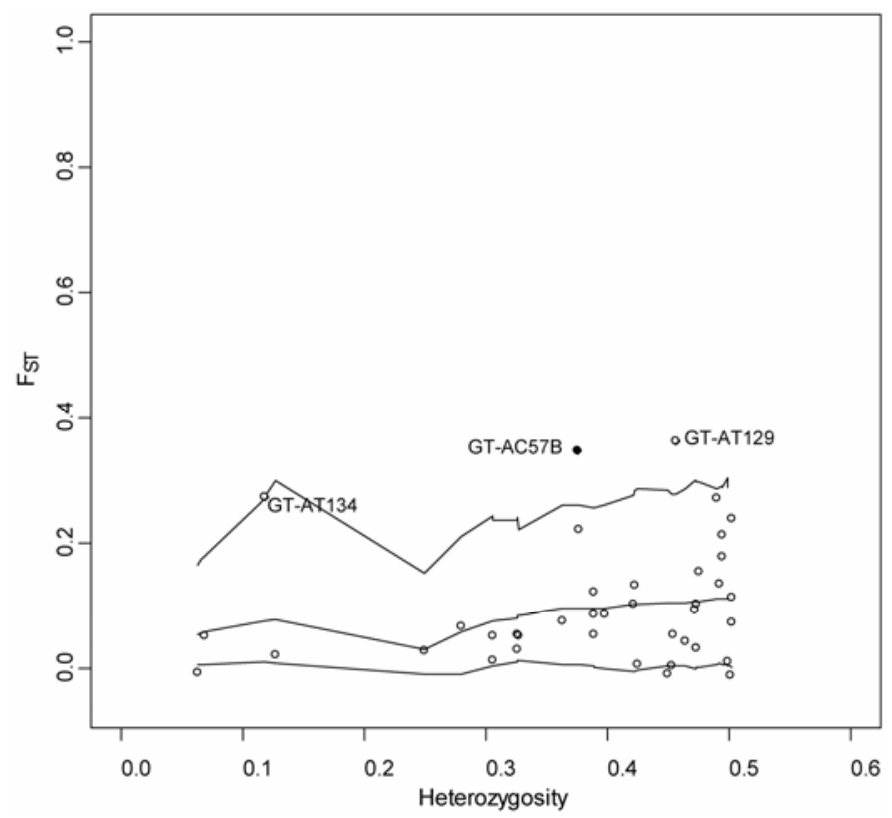

Fig. 5. Estimates of $F_{S T}$ for individual amplified fragment length polymorphism loci (circles) are plotted against simulated heterozygosity (4) using a Bayesian simulation method (3). The lines represent median (middle) and high (0.95) and low (0.05) bounds. One locus, indicated by the filled circle, was significant $(P<0.05)$ after correction for multiple tests using a false discovery rate $(5)$.
AC57B, was significant when a false detection rate of 0.75 was calculated $(P<0.05)$, and this locus was removed from the analyses above. The corrected plus allele frequencies (65) for each site are shown in Figure 6.

\section{DISCUSSION}

The population structure of six western North American sites of C. ribicola estimated from AFLP markers was consistent with that expected for an invasive species with a single introduction. The low percentage of polymorphic loci (i.e., 9.6\%) is similar to the $8 \%$ previously reported using a combination of allozymes, random amplified polymorphism DNA (RAPDs), and restriction fragment length polymorphism (RFLPs) (31). However, western sites of $C$. ribicola are distinct, especially the sites from northern California; Happy Camp and Klamath Mountains (Fig. 2). The number of unique AFLP profiles (146 out of 148) supports a pattern of sexual outcrossing in $C$. ribicola in North American populations $(12,14)$. Despite low polymorphism, genetic diversity is apparently maintained.

The current study and a previous study (31) show a clear genetic differentiation between Happy Camp (the out-plant site for testing resistance performance of sugar pine prescreened for major-gene resistance) and the inland sites (i.e., Roman Nose, Merry Creek, Standley Springs, and Mosca Pass). Two different hypotheses could explain this pattern of genetic differentiation and low heterozygosity at Happy Camp. There was either (i) a genetic bottleneck and drift from founder effects due to geographical distributions of hosts and sites that favor infection (island biogeography hypothesis) or (ii) a genetic bottleneck and drift from major-gene resistant sugar pines that are the overwhelming majority of trees at the site (26), thereby selecting a virulent (vcr1) subpopulation of the rust fungus that can reproduce on this host (selection hypothesis). The genetic distance and heterozygosity among sites is not easily explained under a scenario of a series of strictly geographical founder events and genetic drift. Under this hypothesis, Mosca Pass would be expected to have the least heterozygosity and greatest genetic distance from the other five sites. This population in southern Colorado (established approximately 1987) (7), is $350 \mathrm{~km}$ south of a large population on the Wyoming-Colorado border (established approximately 1952) (21) and is $200 \mathrm{~km}$ north of a small population in New Mexico (established approximately 1998) (D. Conklin, personal communication). The presence of three additional new populations in western New Mexico, but apparent absence of the rust in Utah and Arizona (unpublished data),

\section{Plus allele frequency of GT-AC57B}

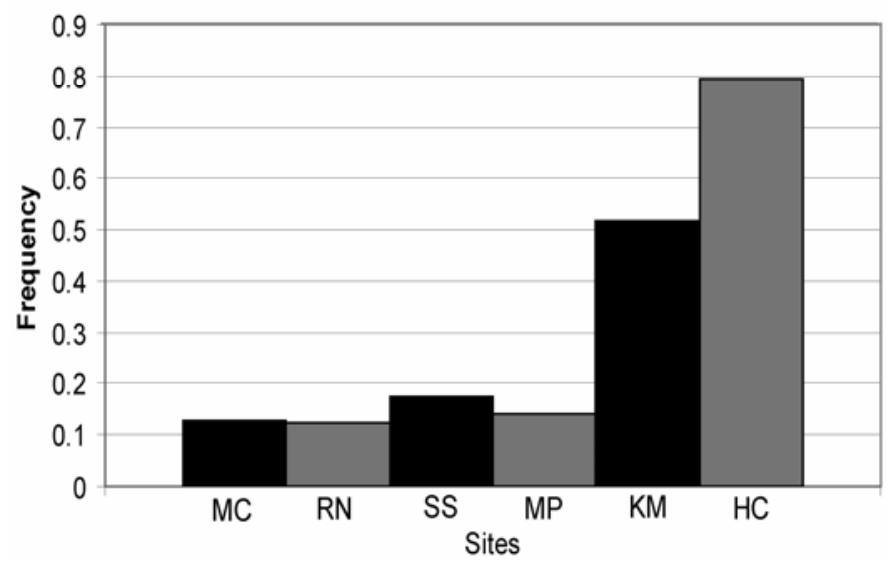

Fig. 6. Corrected (65) plus allele frequency for locus GT-AC57B an outlier identified by DFdist software. 
suggests that the introduction to Mosca Pass may have been by long-distance dispersal $(>1,000 \mathrm{~km})$ from a source genetically typical of natural, inland populations. The rust population in the Klamath Mountains dates to a regional establishment after 1929 (43); the Happy Camp plantation within the Klamath Mountains was established with major-gene resistance selected sugar pine in 1957 (25).

It seems reasonable that the type of host resistance (major-gene resistance versus multigenic resistance) can influence heterozygosity of this pathogen. Plantings at Merry Creek were of F2 progeny of western white pine from a breeding program (6). This material has several putative multigenic resistance traits, demonstrated through inoculation trials $(17,18,38)$ and epidemiological studies (37), but a selective effect on rust has not been demonstrated. Merry Creek had the highest heterozygosity among populations. In contrast, heterozygosity at the Happy Camp site was significantly lower than other inland Northwest sites (Merry Creek, Roman Nose, Standley Springs; $P<0.01$ ). The Happy Camp sugar pine plantation strongly selects for rust isolates carrying the virulence factor, vcr 1 , because plantings carry the $\mathrm{Crl}$ gene (27). Such virulence is very rare and has only been detected at a couple of widely separated locations where $\mathrm{Crl}$ resistant sugar pines are very abundant $(29,30)$.

Diversity of host genetic background should also be considered as an explanation for differences in heterozygosity in the rust fungus. Host plantings at Merry Creek, the site with the highest rust heterozygosity, are a composite host population comprising of progeny from candidate resistant white pine from various locations in northern Idaho (6). Analysis of AFLP markers for western white pine showed that F2 trees derived from the breeding program, analogous to the Merry Creek population, contained higher levels of heterozygosity than local natural stands (23). However, the sugar pine plantation at Happy Camp is also a composite host population representing field-collected progeny of major-gene resistant trees from an even broader geographic range of environments than represented at Merry Creek. Although genetic diversity was not determined for Happy Camp sugar pine, it seems likely that these trees also possess higher genetic diversity than that found in natural sugar pine populations.

Principal coordinates and model-based analyses of individual AFLP profiles determined that two Happy Camp isolates were more similar to isolates of inland northwestern United States sites (population 1 and 2) than to the other Happy Camp isolates assigned to population 3 (Figs. 3 and 4). The two isolates could reflect: (i) first generation or introgressed hybrids between the vcrl-race and the wild type, occurring on major-gene resistant trees, or (ii) non-vcrl isolates from host trees at Happy Camp which were escapes of the screening process that occurred prior to planting and thus do not carry major-gene resistance. Interestingly, the number of isolates that were assigned to population 1 or population 2 was substantially greater for the Klamath site isolates (Fig. 4). Generally, isolates that had low assignment probabilities for population 1 were collected from trees confirmed to not carry major-gene resistance.

One of the objectives of this study was to assess if host specialization could be detected in C. ribicola infecting six species of white pine. Neither principal coordinate analysis nor a model-based approach identified clustering of samples with respect to aecial host (figure not shown). Previous cross-inoculation studies using various Ribes host species and C. ribicola sources have reported differences in infection efficiency and latency, suggesting that $C$. ribicola may adapt locally to Ribes species (36). However, AFLP analyses have not revealed any detectable differences in isolates collected from various Ribes or Pedicularis species among the same population (51). Given that C. ribicola sexually outcrosses, it is likely that if specialization to its telial host has occurred, recombination has sufficiently broken linkages between AFLP loci and the genes involved. Our results also suggest that specialization to pine host is either absent or undetectable at the resolution of our AFLP analysis.

Analysis of individual AFLP markers using $\mathrm{DF}_{\mathrm{DIST}}$ found that three loci exceeded the upper bounds of neutral expectations. Two of these loci (GT-AC57B and GT-AT129) showed frequency disparities between Happy Camp, Klamath Mountains, and other populations (Fig. 6, GT-AC57B shown). However, using a false detection rate (5), suggests that two loci (GT-AT134 and GTAT129) are potentially false positives. This analysis suggests that one locus (GT-AC57B) is an outlier and could be linked to gene(s) under selection. Similar results from this type of analysis have been used in a genetic mapping study of crosses among closely related oak species to identify marker loci linked to genes under selection (54) and to correlate locus frequencies with temperature adaptation in beech (22). Further studies are needed to determine if an association exists between this locus and $v \mathrm{crl}$ virulence to $\mathrm{Crl}$. Inoculations of major-gene resistant and nonmajor-gene resistant sugar pine with Happy Camp/Klamath isolates are planned to determine their virulence status.

Despite losses of genetic diversity in $C$. ribicola through introductions in Europe and North America and its relatively brief, 100-year interaction with new hosts and environments, $C$. ribicola has shown the capacity to naturally infect eight aecial host species, three telial host genera, overcome multiple forms of host resistance, and invade diverse environments. These events affect genetic drift and selection, and have apparently begun to result in distinct populations. Of factors examined thus far, major-gene resistance in sugar pine appears to have had the largest impact on changes in genetic diversity and differentiation. In contrast, hosts containing multigenic resistance had no apparent impact on changes in the rust genetic diversity. In addition, five-needled white pines have been shown to possess the potential of induced resistance, and this could influence the genetic architecture of the rust $(19,41)$. Future genetic studies should also examine the relationships between pathogen genetic structure and diversity with rust incidence and host mortality. Perhaps increased genetic diversity in $C$. ribicola will contribute to a more sustainable white pine blister rust pathosystem whereby both host and pathogen persist at acceptable disease levels. Such information could be valuable in determining how to deploy resistant hosts and manage for a more benign host-pathogen relationship.

\section{ACKNOWLEDGMENTS}

The authors thank P. Hamlett, S. Rogers, Y. Silk, and M. Warwell for field and laboratory assistance, M. Kim for valuable technical advice, D. Burton, D. Davis, J. Blodgett, and K. Burns for providing rust samples and site data, and T. Peever, J. Rogers, and two anonymous reviewers for their suggestions to improve this manuscript. This project was funded by the Forest and Woodland Ecosystem Program at the Forest Sciences Laboratory, Moscow, Idaho.

\section{LITERATURE CITED}

1. Altizer, S., Harvell, D., and Friedle, E. 2003. Rapid evolutionary dynamics and disease threats to biodiversity. Trends Ecol. Evol. 18:589-596.

2. Anagnostakis, S. L. 1987. Chestnut blight: The classical problem of an introduced pathogen. Mycologia 79:23-37.

3. Beaumont, M. A., and Balding, D. J. 2004. Identifying adaptive genetic divergence among populations from genome scans. Mol. Ecol. 13:969980 .

4. Beaumont, M. A., and Nichols, R. A. 1996. Evaluating loci for use in the genetic analysis of population structure. Proc. R. Soc. Lond. Ser-B. 263:1619-1626.

5. Benjamini, Y., and Hochberg, Y. 1995. Controlling the false discovery rate: A practical and powerful approach to multiple testing. J. Roy. Stat. Soc. Ser-B (Methodological). 57:289-300.

6. Bingham, R. T. 1983. Blister rust resistant western white pine for the Inland Empire: The story of the first 25 years of the research and development program. U.S. Dept. Agric. For. Ser. Gen. Tech. Rep. INT-146. Intermountain Forest and Range Experiment Station, Ogden, UT. 
7. Blodgett, J. T., and Sullivan, K. F. 2004. First report of white pine blister rust on Rocky Mountain Bristlecone Pine. Plant Dis. 88:311.

8. Burdon, J. J., Thrall, P. H., and Ericson, L. 2005. The current and future dynamics of disease in plant communities. Annu. Rev. Phytopathol. 44:19-39.

9. Et-touil, K., Bernier, L., Beaulieu, J., Bérubé, J. A., Hopkin, A., and Hamelin, R. C. 1999. Genetic structure of Cronartium ribicola populations in eastern Canada. Phytopathology 89:915-919.

10. Felsenstein, J. 1995. PHYLIP (Phylogeny Inference Package) version 3.57 c. Department of Genetics, University of Washington, Seattle.

11. Flor, H. H. 1955. Host-parasite interaction in flax rust- its genetics and other implications. Phytopathology 45:680-685.

12. Gitzendanner, M. A., White, E. E., Foord, B. M., Dupper, G. E., Hodgskiss, P. D., and Kinloch, B. B., Jr. 1996. Genetics of Cronartium ribicola. III. Mating system. Can. J. Bot. 74:1852-1859.

13. Hamelin, R. C. 1996. Genetic diversity between and within cankers of the white pine blister rust. Phytopathology 86:875-879.

14. Hamelin, R. C., Allaire, M., Bergeron, M.-J., Nicole, M.-C., and Lecours, N. 2005. Molecular epidemiology of white pine blister rust: Recombination and spatial distribution. Phytopathology 95:793-799.

15. Hamelin, R. C., Dusabenyagasani, M., and Et-touil, K. 1998. Fine-level genetic structure of white pine blister rust populations. Phytopathology 88:1187-1191

16. Hamelin, R. C., Hunt, R. S., Geils, B. W., Jensen, G. D., Jacobi, V., and Lecours, N. 2000. Barrier to gene flow between eastern and western populations of Cronartium ribicola in North America. Phytopathology 90:1073-1078.

17. Hoff, R. J., and McDonald, G. I. 1971. Resistance to Cronartium ribicola in Pinus monticola: Short shoot fungicidal reaction. Can. J. Bot. 49:12351239.

18. Hoff, R. J., and McDonald, G. I. 1980. Resistance to Cronartium ribicola in Pinus monticola: Reduced needle-spot frequency. Can. J. Bot. 58:574577.

19. Hudgins, J. W., McDonald, G. I., Zambino, P. J., Klopfenstein, N. B., Franceschi, V. R. 2005. Anatomical and cellular responses of Pinus monticola stem tissues to invasion by Cronartium ribicola. Forest Pathol. 35:423-443.

20. Hunt, R. S. 2003. White pine blister rust. Rec. Res. Dev. Mycol. 1:73-85.

21. Johnson, D. W., and Jacobi, W. R. 2000. First report of white pine blister rust in Colorado. Plant Dis. 84:595.

22. Jump, A. S., Hunt, J. M., Martinez-Izquierdo, J. A., and Penuelas, J. 2006. Natural selection and climate change: temperature-linked spatial and temporal trends in gene frequency in Fagus sylvatica. Mol. Ecol. $15: 3469-3480$

23. Kim, M. S., Brunsfeld, S. J., McDonald, G. I., and Klopfenstein, N. B. 2003. Effect of white pine blister rust (Cronartium ribicola) and rustresistance breeding on genetic variation in western white pine (Pinus monticola). Theor. Appl. Genet. 106:1004-1010.

24. Kinloch, B. B., Jr. 1992. Distribution and frequency of a gene for resistance to white pine blister rust in natural populations of sugar pine. Can. J. Bot. 70:1319-1323.

25. Kinloch, B. B., Jr., and Byler, J. W. 1981. Relative effectiveness and stability of different resistance mechanisms to white pine blister rust in sugar pine. Phytopathology 71:386-391

26. Kinloch, B. B., Jr., and Comstock, M. 1981. Race of Cronartium ribicola virulent to major gene resistance in sugar pine. Plant Dis. 65:604-605.

27. Kinloch, B. B., Jr., and Dupper, G. E. 2002. Genetic specificity in the white pine-blister rust pathosystem. Phytopathology 92:278-280.

28. Kinloch, B. B., Jr., Sniezko, R. A., Barnes, G. D., and Greathouse, T. E. 1999. A major gene for resistance to white pine blister rust in western white pine from the western Cascade Range. Phytopathology 89:861-867.

29. Kinloch, B. B., Jr., Sniezko, R. A., and Dupper, G. E. 2003. Origin and distribution of $\mathrm{Cr} 2$, a gene for resistance to white pine blister rust in natural populations of western white pine. Phytopathology 93:691-694.

30. Kinloch, B. B., Jr., Sniezko, R. A., and Dupper, G. E. 2004. Virulence gene distribution and dynamics of the white pine blister rust pathogen in western North America. Phytopathology 94:751-758.

31. Kinloch, B. B., Jr., Westfall, R. D., White, E. E., Gitzendanner, M. A., Dupper, G. E., Foord, B. M., and Hodgskiss, P. D. 1998. Genetics of Cronartium ribicola. IV. Population structure in western North America. Can. J. Bot. 76:91-98.

32. Laine, A. L. 2004. Resistance variation within and among host populations in a plant-pathogen metapopulation: Implications for regional pathogen dynamics. J. Ecol. 92:990-1000.

33. Lee, C. E. 2002. Evolutionary genetics of invasive species. Trends Ecol. Evol. 17:386-391.

34. Lynch, M., and Milligan, B. G. 1994. Analysis of population genetic structure with RAPD markers. Mol. Ecol. 3:91-99.

35. Maloy, O. C. 1997. White pine blister rust control in North America: A Case History. Annu. Rev. Phytopathol. 35:87-109.
36. McDonald, G. I. 2000. Geographic variation of white pine blister rust aeciospore infection efficiency and incubation period. HortTechnology 10:533-536.

37. McDonald, G. I., and Dekker-Robertson, D. L. 1998. Long-term differential expression of blister rust resistance in western white pine. Proc. First IUFRO Rusts For. Trees Working Party Conf. R. Jalkanen, P. Crane, J. Walla, and T. Aalto, eds. Finn. For. Res. Inst. Res. Pap. 712:285295.

38. McDonald, G. I., and Hoff, R. J. 1970. Resistance to Cronartium ribicola in Pinus monticola: Early shedding of infected needles. USDA Forest Service Research Note INT-124, Intermountain Forest and Range Experiment Station Ogden, UT.

39. McDonald, G. I., and Hoff, R. J. 2001. Blister rust: An introduced plague. Pages 193-200 in: Whitebark Pine Communities: Ecology and Restoration. D. F. Tomback, S. F. Arno, and R. E. Keane, eds. Island Press, Washington, DC.

40. McDonald, G. I., Richardson, B. A., Zambino, P. J., Klopfenstein, N. B., and Kim, M. S. 2006. Pedicularis and Castilleja are natural hosts of Cronartium ribicola in North America: A first report. For. Pathol. 36:7382.

41. McDonald, G., Zambino, P., and Sniezko, R. 2004. Breeding rust-resistant five-needle pines in the western United States: Lessons from the past and a look to the future. Pages 28-50 in: Breeding and Genetic Resources of Five-needle Pines: Growth, Adaptability, and Pest Resistance. R. A. Sniezko, S. Samman, S. E. Sclarbaum, and H. B. Kriebel, eds. IUFRO Working Party 2.02.15A Proc. RMRS-P-32, U.S. Dept. Agric. For. Service, Rocky Mountain Research Station, Fort Collins, CO.

42. McDonald, G. I., Zambino, P. J., and Klopfenstein, N. B. 2005. Naturalization of host-dependent microbes after introduction into terrestrial ecosystems. Pages 41-58 in: Forest Pathology: From Genes to Landscapes. J. E. Lundquist, and R. C. Hamelin, eds. American Phytopathological Society, St. Paul, MN.

43. Mielke, J. L. 1938. Spread of blister rust to sugar pine in Oregon and California. J. Forest. 36:695-701.

44. Mielke, J. L. 1943. White pine blister rust in western North America. Yale University School of Forestry Bull. 52:1-155.

45. Nei, M. 1978. Estimation of average heterozygosity and genetic distance from a small number of individuals. Genetics 89:583-590.

46. Patton, R. F., and Riker, A. J. 1966. Lessons from nursery and fieldtesting of eastern white pine selections and progenies for resistance to blister rust. Pages 403-414 in: Breeding Pest-Resistant Trees. H. D. Gerhold, ed. Pergamon Press, University Park, PA.

47. Pritchard, J. K., Stephens, M., and Donnelly, P. 2000. Inference of population structure using multilocus genotype data. Genetics 155:945959.

48. Remington, D. L., Whetten, R. W., Liu, B. H., and O’Malley, D. M. 1999. Construction of an AFLP genetic map with nearly complete genome coverage in Pinus taeda. Theor. Appl. Genet. 98:1279-1292.

49. Reznick, D. N., and Ghalambor, C. K. 2001. The population ecology of contemporary adaptations: What empirical studies reveal about the conditions that promote adaptive evolution. Genetica 112:183-198.

50. Richardson, B. A., Brunsfeld, S. J., and Klopfenstein, N. B. 2002. DNA from bird-dispersed seed and wind-disseminated pollen provides insights into postglacial colonization and population genetic structure of whitebark pine (Pinus albicaulis). Mol. Ecol. 11:215-227.

51. Richardson, B. A., Zambino, P. J., Klopfenstein, N. B., McDonald, G. I., and Carris, L. M. 2007. Assessing host specialization among aecial and telial hosts of the white pine blister rust fungus, Cronartium ribicola. Can. J. Bot. 85:299-306.

52. Rohlf, F. J. 1998. NTSYS-PC. Numerical taxonomy and multivariate analysis system. Exeter Software, Setauker.

53. Sala, O. E., Chapin, F. S., Armesto, J. J., Berlow, E., Bloomfield, J., Dirzo, R., Huber-Sanwald, E., Huenneke, L. F., Jackson, R. B., and Kinzig, A. 2000. Global biodiversity scenarios for the year 2100. Science 287:1770-1774.

54. Scotti-Saintagne, C., Mariette, S., Porth, I., Goicoechea, P. G., Barreneche, T., Bodenes, C., Burg, K., and Kremer, A. 2004. Genome scanning for interspecific differentiation between two closely related oak species (Quercus robur L. and Q. petraea [Matt.] Liebl.). Genetics 168:1615-1626

55. Spaulding, P. 1911. The blister rust of white pine. USDA. Bur. Plant Ind. Bull. 206:1-81.

56. Thompson, J. N. 1998. Rapid evolution as an ecological process. Trends Ecol. Evol. 13:329-332.

57. Thrall, P. H., Barrett, L. G., Burdon, J. J., and Alexander, H. M. 2005. Variation in pathogen aggressiveness within a metapopulation of the Cakile maritima-Alternaria brassicicola host-pathogen association. Plant Pathol. 54:265-274.

58. Thrall, P. H., and Burdon, J. J. 2003. Evolution of virulence in a plant host-pathogen metapopulation. Science 299:1735-1737. 
59. Thrall, P. H., Burdon, J. J., and Bever, J. D. 2002. Local adaptation in the Linum marginale-Melampsora lini host-pathogen interaction. Evolution 56:1340-1351.

60. Thrall, P. H., Burdon, J. J., and Young, A. 2001. Variation in resistance and virulence among demes of a plant host-pathogen metapopulation. J. Ecol. 89:736-748.

61. Vekemans, X. 2002. AFLP-SURV. Distributed by the author, Laboratorie de Genetique et Ecologie Vegetale, Universitie Libre de Bruxelles, Belguim.

62. Vos, P., Hogers, R., Bleeker, M., Reijans, M., van de Lee, T., Hornes, M., Frijters, A., Pot, J., Peleman, J., and Kuiper, M. 1995. AFLP: A new technique for DNA fingerprinting. Nucleic Acids Res. 23:4407-4414.
63. White, E. E., Foord, B. M., and Kinloch, B. B., Jr. 1996. Genetics of Cronartium ribicola. II. Variation in the ribosomal gene cluster. Can. J. Bot. 74:461-468.

64. Zambino, P. 2000. Assessing Ribes for blister rust resistance using controlled inoculations. Published online by USDA Forest Service, North Central Research Station, Forest Sciences Laboratory. http://www.arsgrin. gov/cor/wpbrmeet/abstracts.html.

65. Zambino, P. J. 2002. Dry grinding at near-ambient temperatures for extracting DNA from rust and other fungal spores. Biotechniques 33:4851.

66. Zhivotovsky, L. A. 1999. Estimating population structure in diploids with multilocus dominant DNA markers. Mol. Ecol. 8:907-913. 